\title{
Mechanism of the Growth Inhibitory Effect of Cysteine on Escherichia coli
}

\author{
By C. KARI*, Z. NAGY, P. KOVÁCS AND F. HERNÁDI \\ Department of Pharmacology, University Medical School, Debrecen I2, Hungary
}

(Accepted for publication 4 August 197I)

\section{SUMMARY}

Cysteine appeared to have two classes of growth inhibitory effect on Escherichia coli: (I) above 0.2 mmit inhibited growth on minimal medium by a mechanism which may involve interference with leucine, isoleucine, threonine and valine biosynthesis; (2) above $2 \mathrm{~mm}$, in media with these amino acids, it had an effect which may involve interaction with membrane bound respiratory enzymes.

Cysteamine showed only effect (2).

\section{INTRODUCTION}

Roberts, Abelson, Cowie, Bolton \& Britten (I957) reported that exogenous cysteine inhibits the growth of Escherichia coli, but the mechanism of this action is still unclarified. Nagy, Hernádi, Kovács, Vályi-Nagy (I968a) and Nagy, Kovács, Kari \& Hernádi (I970) found that, in $E$. coli $\mathrm{I}_{5} \mathrm{~T}^{-}$, the net synthesis of RNA and protein, but not that of DNA, was quickly inhibited by cysteine. An antagonism could be detected between cysteine and leucine (leu), isoleucine (ileu), threonine (threo) and valine (val) and it was suggested that the biosynthesis of these amino acids (AAs) is inhibited by cysteine (Kovács, Kari, Nagy \& Hernádi, 1968). However, not all the effects of cysteine could be explained in this way (Nagy, Kari \& Hernádi, I969).

Since cysteine is an extremely reactive compound it is not surprising that it affects several enzymic reactions in vitro (Komlós \& Erdős, I959; Leavitt \& Umbarger, 1961; Datta, 1967; Alföldi, Raskó \& Kerekes, I968) and a number of metabolic functions in Escherichia coli, as well as in other micro-organisms (Roberts et al. 1957; Pasternak, I962; Bhuvanesvaran \& Sreenivasan, I964; Bernheim, I966; Koningsberger, 1967; Nagy, Hernádi et al. $1968 a$, I $968 b$, 1969, 1970; Nagy, Kovács, Balázs \& Hernádi, I968; Kari, Nagy \& Hernádi, I97I). Each of these effects may be responsible for its cytotoxic action, but it is difficult to demonstrate which of these many reactions is involved in growth inhibition. Enzyme experiments in vitro and the various metabolic actions of cysteine need to be assessed in the light of detailed growth studies.

\section{METHODS}

Bacterial strains. Escherichia coli strain B (prototroph, from T. Alper of Hammersmith Hospital, London); Hfr CAVAll $\mathrm{met}^{-} \mathrm{rel}^{-}$(a relaxed strain, auxotrophic for methionine); CP $99 \mathrm{his}^{-} \mathrm{arg}^{-} \mathrm{ser}^{-} \mathrm{B}_{1}^{-} \mathrm{rel}^{+}$(a stringent strain, auxotrophic for histidine, arginine, serine and $\mathrm{B}_{1}$ ); and CP 100 his $^{-}$arg $^{-}$ser- $^{-} \mathbf{B}_{1}^{-}$rel- $^{-}$(a relaxed mutant of CP99). The latter three strains were obtained from L. Alföldi (Medical University of Szeged, Hungary).

Growth. Organisms were cultivated on mineral salts medium C (Roberts et al. 1957)

* Present address: Institute of Genetics, Biological Centre, Hungarian Academy of Sciences, Szeged, P.O.B. 521 , Hungary. 
supplemented with $0.5 \%(\mathrm{w} / \mathrm{v})$ glucose; when required, amino acids (AAs) were added to $50 \mu \mathrm{g}$ each $/ \mathrm{ml}$. and vitamin $\mathrm{B}_{1}$ (as thiamine $\mathrm{HCl}$ ) to $5 \mu \mathrm{g} / \mathrm{ml}$. Overnight cultures were diluted 30 -fold in prewarmed fresh medium and incubated aerobically at $37^{\circ}$ in a water-bath shaker. The extinction $(E)$ of cultures was measured with a Spectromom 360 spectrophotometer at $550 \mathrm{~nm}$. using $0.5 \mathrm{~cm}$. cuvettes. Exponentially growing cultures were used in all experiments. A formula for the calculation of growth inhibition was described earlier (Nagy et al. 1968b).

\section{Incorporation of labelled compounds}

$\left[{ }^{14} \mathrm{C}\right]$-uracil. For the measurement of net RNA synthesis, cultures were exposed to labelled uracil ( $0 . \mathrm{I} \mu \mathrm{Ci} / 30 \mu \mathrm{g} . / \mathrm{ml}$.) and grown as described above. At intervals, duplicate $\mathrm{I} \mathrm{ml}$. samples were taken and added to $4 \mathrm{ml}$. ice-cold trichloroacetic acid (TCA, final concentration $5 \%$ ). After $60 \mathrm{~min}$. the precipitates were collected on membrane filters (Sartorius MF I4), washed three times with Io $\mathrm{ml}$. cold $5 \%$ TCA, glued to aluminium planchettes and counted in a windowless gas-flow counter (Gamma, Budapest).

$\left[{ }^{35} \mathrm{~S}\right]$-sulphate. Bacteria were grown in mineral salts-glucose medium containing $0 \cdot 2 \mu \mathrm{Ci}$ ${ }^{35} \mathrm{~S}$ as $26 \cdot 7 \mu \mathrm{g}$. $\left[{ }^{35} \mathrm{~S}\right]$-sulphate per $\mathrm{ml}$. The radiosulphate incorporation into the cold TCAinsoluble fraction was determined as described above.

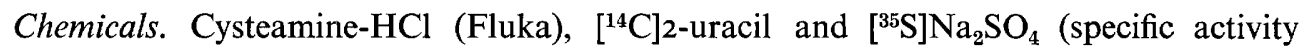
$25.35 \mathrm{mCi} / \mathrm{mmole}$ and $26 \mathrm{mCi} / \mathrm{mmole}$ respectively, NAEC Institute of Isotopes, Budapest) were used. All other chemicals used were reagent grade as obtained from Reanal (Budapest). Cysteamine (MEA) and cysteine (L-cysteine- $\mathrm{HCl} . \mathrm{I} \mathrm{H}_{2} \mathrm{O}$ ) were sterilized by filtration. Only the freshly prepared solutions of these compounds were used.

Stability of cysteine. Under our experimental conditions (liquid culture medium, aeration by shaking, $\mathrm{pH} 6 \cdot 5$ to $7 \cdot 0$ ) cysteine decomposes. Nagy et al. (1969) established that the rate of decomposition of cysteine was independent of initial cysteine concentration between $0 \cdot 2$ and $40 \mathrm{~mm}$ and that about $20 \%$ of the cysteine decomposed during $60 \mathrm{~min}$. Our growth tests reported here were made during this time. The compounds added did not affect the stability of cysteine or MEA; the stability of the latter compound was measured by the Ellman's method (Ellman, I959).

\section{RESULTS}

Growth studies. Growth of Escherichia coli is inhibited by cysteine (Roberts et al. I957; Nagy, Hernádi et al. 1968 b), but resumes at the normal exponential rate after removal of the cysteine from the medium (Nagy et al. 1970). Fig. I shows the progressive inhibition of growth of $E$. coli $\mathrm{B}$ with increasing cysteine concentration. The first significant growth inhibition was observed with $0.2 \mathrm{~mm}$-cysteine and almost complete inhibition was obtained with Io mMcysteine (Fig. I, curve A). This growth inhibitory effect of cysteine was partially relieved by simultaneous addition of leu, ileu, threo or val (Kovács et al. I968), leu and ileu being more effective than threo and val. The most powerful anti-cysteine action was obtained with a mixture of all four (Table I). Only the L-forms of these AAs were effective, the D-isomers of the other three AAs behaving as the ileu shown in Table I. The growth inhibitory effect of cysteine was not overcome by other AAs, nor-leu, nor-val, $N$-acetyl-val, benzoyl-val, or by uracil.

Growth of Escherichia coli в was inhibited by cysteine at concentrations higher than $2 \mathrm{mM}$, even in the presence of a mixture of leucine, isoleucine, threonine and valine (leu-ileu-threoval), but to a considerably lesser extent than in their absence (Fig. I, curve B).

The growth inhibitory effect of MEA was also analysed. Fig. I shows that MEA was about as effective in inhibiting growth as was cysteine in the presence of leu-ileu-threo-val. 


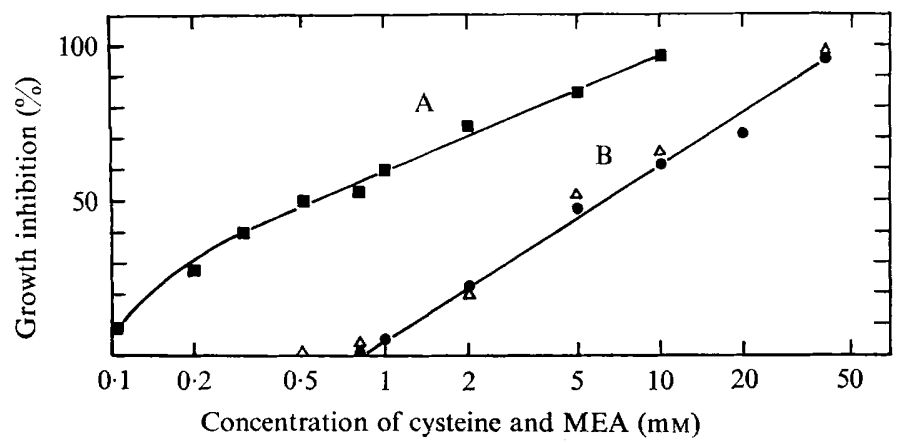

Fig. I. Progressive inhibition of growth of Escherichia coli $\mathrm{B}$ with increasing concentrations of cysteine and MEA. Escherichia coli B was grown aerobically on Roberts C mineral salts-glucose medium and the cultures in mid-log phase were treated as follows: $\mathbf{\square}$, cysteine; $\boldsymbol{O}$, cysteine + leuileu-threo-val (50 $\mu \mathrm{g} . / \mathrm{ml}$. of each); $\triangle$, MEA. The degree of growth inhibition was calculated as described by Nagy et al. (1968 b).

Table 1. Effect of leu, ileu, threo and val on inhibition of growth of Escherichia coli в by 2 mм cysteine

Escherichia coli в was grown aerobically on Roberts C mineral salts-glucose medium at $37^{\circ}$. Logarithmically growing cultures were treated with the compounds indicated. Leu, ileu, threo and val were each added to $50 \mu \mathrm{g} . / \mathrm{ml}$. The degree of growth inhibition was calculated as described by Nagy, Hernádi et al. (1968b).

\begin{tabular}{lc}
\multicolumn{1}{c}{ Treatments } & $\begin{array}{c}\text { Growth inhibition } \\
\text { Cysteine }\end{array}$ \\
Cysteine + L-leu & 76 \\
Cysteine + L-ileu & 40 \\
Cysteine + L-threo & 42 \\
Cysteine + L-val & 52 \\
Cysteine + L-leu-ileu-threo-val & 54 \\
Cysteine + L-ileu & 20 \\
Cysteine + D-ileu & 42 \\
Cysteine + DL-ileu & 71 \\
\end{tabular}

No antagonism was detected between MEA and the above-mentioned compounds, including leu-ileu-threo-val.

Effect of cysteine on $\left[{ }^{14} \mathrm{C}\right]$-uracil incorporation into $\mathrm{rel}^{-}$and $\mathrm{rel}^{+}$strains. We presented evidence that cysteine does not directly inhibit RNA synthesis in Escherichia coli в (Kari et al. I97I) and suggested that cessation of RNA synthesis in the presence of cysteine might be the consequence of inhibition of biosynthesis of leu, ileu, threo and val. This implies that cysteine may inhibit net synthesis of RNA via the action of rel gene. If this were true, one would expect to find that cysteine treatment induces a similar pattern of incorporation of labelled uracil as does AA deprivation in a $\mathrm{rel}^{-}$mutant of $E$. coli. In this section we describe experiments to test this prediction.

Escherichia coli Hfr CAVALLI met $^{-}$rel $^{-}$was grown to mid-log phase in glucose-mineral salts medium containing $\left[{ }^{14} \mathrm{C}\right]$-uracil. The culture was then treated with cysteine $(2 \mathrm{~mm})$ and the methionine was simultaneously withdrawn. Unexpectedly, net RNA synthesis was inhibited by cysteine in this relaxed strain (Fig. 2). Leu-ileu-threo-val had no affect on this action of cysteine. Similar results were obtained when 20 mM MEA was used in place of cysteine. On the other hand, if methionine was also present at the time of cysteine treatment leu-ileuthreo-val completely abolished the inhibitory effect of cysteine (Fig. 3). 
These experiments were repeated with another three strains with similar results. Thus, the inhibitory effect of cysteine on net RNA biosynthesis could not be attributed to the action of rel gene.

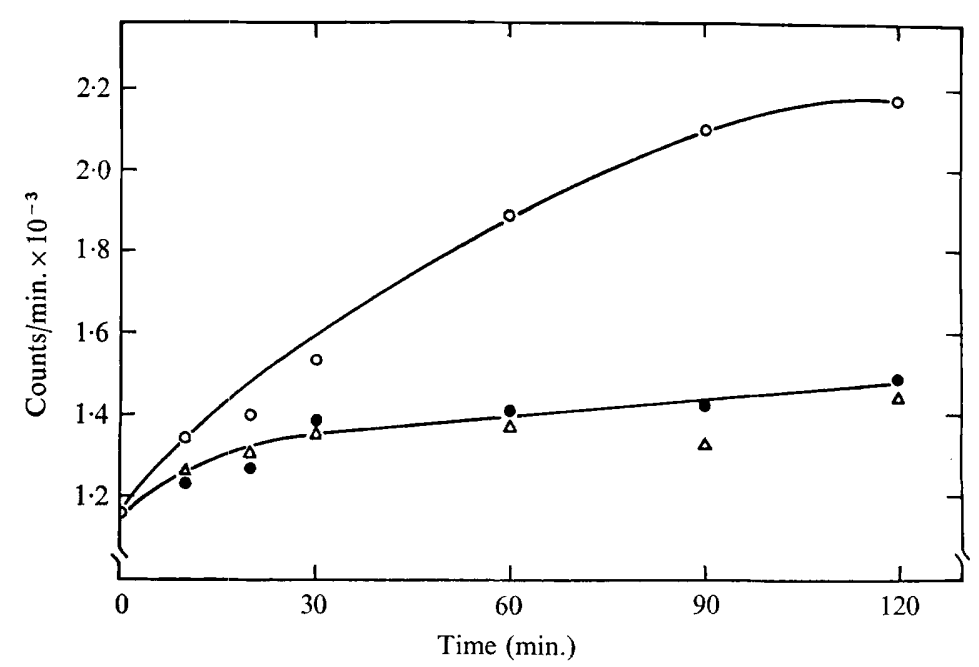

Fig. 2. Effect of cysteine on $\left.{ }^{14} \mathrm{C}\right]-$ uracil incorporation into Escherichia coli Hfr CAVALLI met $^{-}$rel $^{-}$ during methionine starvation. Bacteria were grown on Roberts C-glucose-methionine $(50 \mu \mathrm{g} . / \mathrm{ml}$.) medium supplemented with $\left[{ }^{14} \mathrm{C}\right]$-uracil $(0 \cdot 1 \mu \mathrm{Ci} / 30 \mu \mathrm{g}$. $/ \mathrm{ml}$ ). Organisms in the mid-log phase of growth were centrifuged, washed three times and resuspended in the same, warmed, but methionine-free medium. The culture was divided into 3 portions, treated and incubated further at $37^{\circ}$. Treatments (at o min.): $\bigcirc$, control; $\bullet, 2 \mathrm{mM}$-cysteine; $\triangle, 2 \mathrm{mM}$-cysteine $+50 \mu \mathrm{g}$. $/ \mathrm{ml}$. of each of leu-ileu-threo-val. The incorporation of labelled uracil was measured as described in Methods.

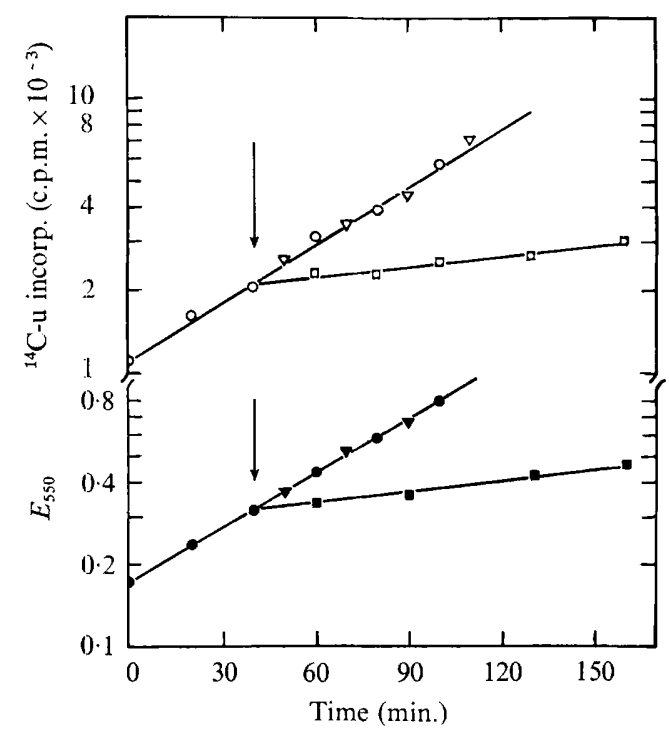

Fig. 3. Effect of cysteine on $\left[{ }^{14} \mathrm{C}\right]$-uracil incorporation into Escherichia coli Hfr cavalu met $^{-}$rel $^{-}$. Bacteria were grown as described in the legend to Fig. 2 and in the mid-log phase of growth were treated at the indicated time as follows: $\bigcirc, \boldsymbol{\bullet}$, control; $\square, \boldsymbol{\square}, 2 \mathrm{~mm}$ cysteine; $\nabla, \nabla, 2 \mathrm{~mm}$ cysteine $+50 \mu \mathrm{g} . / \mathrm{ml}$. of each of leu-ileu-threo-val. The extinction $(\boldsymbol{\nabla}, \boldsymbol{\nabla}, \boldsymbol{\nabla})$ and ${ }^{\left.1{ }^{14} \mathrm{C}\right] \text {-uracil }}$ incorporation $(O, \square, \nabla)$ were measured as described in Methods. 
Breakdown of preformed 'relaxed' RNA during cysteine treatment. Dalgarno \& Gros (I968) reported that net synthesis of 'relaxed' RNA ceases after incubating Escherichia coli $\mathrm{EA}_{2}\left(\mathrm{met}^{-} \mathrm{rel}^{-}\right)$in the absence methionine for $150 \mathrm{~min}$.; subsequent incubation at $37^{\circ}$ without an energy source, or with 2,4-dinitrophenol, induces a rapid breakdown of labelled 'relaxed' RNA. This was confirmed by glucose omission (Fig. 4). A similar breakdown was observed with glucose and $2 \mathrm{mM}$-cysteine. When glucose was omitted at the time of cysteine addition, no additional breakdown was obtained (not shown in Figure), indicating a common mechanism for these two treatments. This effect of cysteine was not influenced by leuileu-threo-val. Similar results were obtained when MEA (20 mM) was used in place of cysteine.

This suggests that the 'MEA-like' effect of cysteine induces an energy depletion of bacteria.

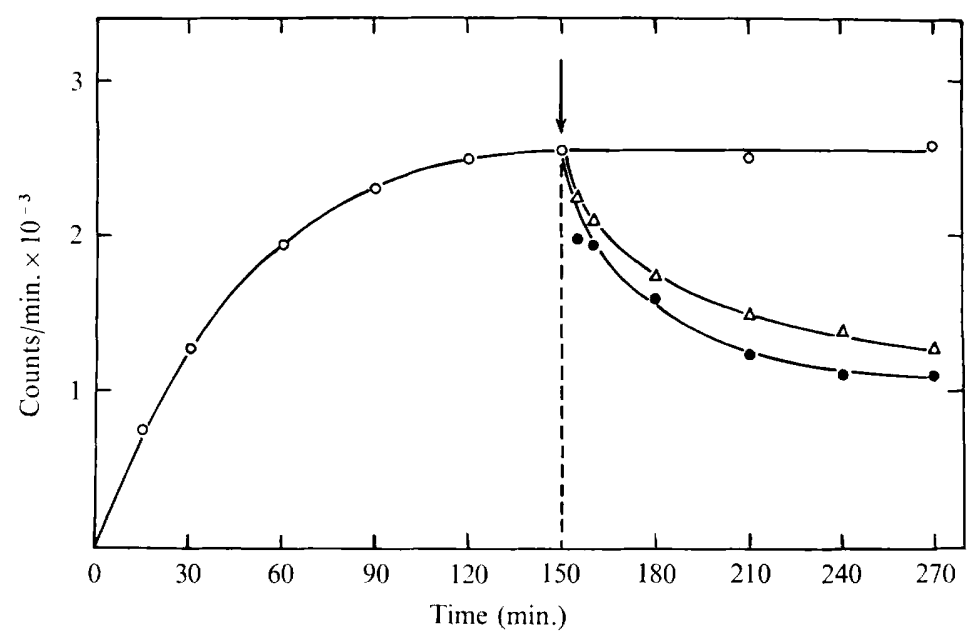

Fig. 4. Breakdown of 'relaxed' RNA during cysteine treatment in Escherichia coli Hfr CAVALLI mel' $\mathrm{rel}^{-}$cells. Bacteria were grown to mid-log phase on Roberts C-glucose-methionine (50 $\mu \mathrm{g} . / \mathrm{ml}$.) medium. The organisms were washed free of methionine (see the legend to Fig. 2), resuspended in Roberts C-glucose- $\left[{ }^{14} \mathrm{C}\right]$-uracil $\left(0 \cdot 2 \mu \mathrm{Ci} / 30 \mu \mathrm{g}\right.$. $/ \mathrm{ml}$.) medium and incubated at $37^{\circ}$. After $\mathrm{I} 50 \mathrm{~min}$. the bacteria were treated as described below and reincubated at $37^{\circ}$ for a further $\mathrm{I} 20$ min. Treatments: $\bigcirc$, control;, , glucose omission (centrifugation, washing three times and resuspension in Roberts $\mathrm{C}-\left[{ }^{14} \mathrm{C}\right]$-uracil medium); $\triangle, 2 \mathrm{~mm}$-cysteine. Acid-precipitable radioactivity was determined as described in Methods.

Effect of cysteine on $\left[{ }^{35} S\right]$-sulphate incorporation. Incorporation of radiosulphate into various micro-organisms is prevented by cysteine (Roberts et al. 1957; Pasternak, 1962). In the case of Escherichia coli, however, cystine was used instead of cysteine, since the former compound fails to inhibit the growth of $E$. coli. Nevertheless, it was suggested that cysteine is the actual repressor of sulphate activating enzymes in E. coli (Wheldrake, 1967; JonesMortimer, 1968).

The effect of cysteine on $\left[{ }^{35} \mathrm{~S}\right]$-sulphate incorporation could be measured without growth inhibition when the bacteria were cultured in glucose-mineral salts medium supplemented with leu-ileu-threo-val. Fig. 5 shows that the incorporation of radiosulphate ceased immediately after the addition of cysteine, but that growth continued at the same rate (cysteine was used at a concentration of $0.82 \mathrm{~mm}$, the sulphur content of which equals that of the medium). When MEA was added to the culture at the above concentration no change was detected in the incorporation of $\left[{ }^{35} \mathrm{~S}\right]$-sulphate. 
These results agree with those cited above, as well as with Ginsberg's (I966) and with our previous data (Kovács et al. I968; Nagy et al. I969; Nagy \& Quintiliani, 1970).

\section{DISCUSSION}

We have clearly distinguished between two kinds of growth inhibitory effect of cysteine on Escherichia coli. These will be called primary and secondary effects of cysteine.

When the organisms are cultured on glucose-mineral salts medium, growth is inhibited by the primary effect. The mechanism of this effect can be deduced from the following data: (i) the most powerful antagonism of cysteine was obtained using very low $(50 \mu \mathrm{g} . / \mathrm{ml}$.) concentration of leu-ileu-threo-val (Fig. I); (ii) cysteine inhibited the inducible synthesis of

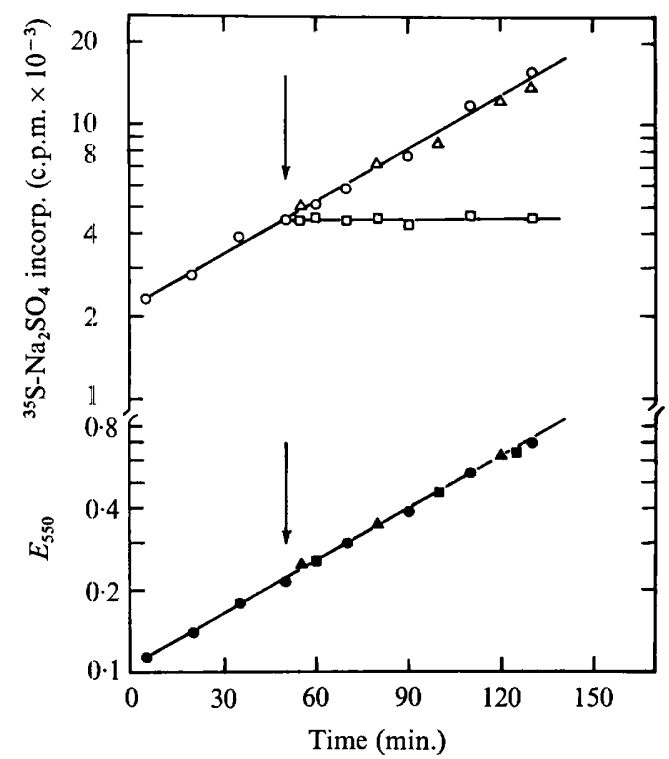

Fig. 5. Effect of cysteine and MEA on $\left[{ }^{35} \mathrm{~S}\right]$-sulphate utilization of Escherichia coli $\mathrm{B}$. Bacteria were grown on Roberts C-glucose-leu-ileu-threo-val medium ( $50 \mu \mathrm{g} . / \mathrm{ml}$. of each), containing ${ }^{35} \mathrm{~S}^{-N_{2}} \mathrm{SO}_{4}$ $(0.2 \mu \mathrm{Ci} / 26.7 \mu \mathrm{g}$. $/ \mathrm{ml}$.). At the indicated time the organisms were treated as follows: 0 , 0 , control; $\square, \boldsymbol{\square}, 0.84 \mathrm{~mm}$-cysteine; $\triangle, \boldsymbol{\Delta}, 0.84 \mathrm{~mm}$-MEA. The extinction $(\boldsymbol{O}, \boldsymbol{\square}, \boldsymbol{\Delta})$ and radio-sulphate incorporation $(\bigcirc, \square, \triangle$ ) were measured as described in Methods.

$\beta$-galactosidase in a manner reminiscent of the way in which synthesis of this enzyme is prevented by withdrawal of a required AA from an auxotrophic mutant. This action was also overcome by addition of leu-ileu-threo-val (Kari et al. I 97I); (iii) there are two enzymes, concerned in the biosynthesis of these four AAs in E. coli, which are inhibited in vitro by cysteine: homoserine dehydrogenase (HSDH, Datta, I967, 1969) and acetohydroxy acid synthetase (AHAS, Leavitt \& Umbarger, 196I). A good quantitative correlation exists between the degree of growth inhibitory and enzyme inhibitory effects of cysteine (Fig. I, curve A; Fig. I of Datta, I967; Table 4 of Leavitt \& Umbarger, I96I, respectively). If the activities of HSDH and AHAS are simultaneously inhibited by cysteine the bacteria will be starved for threo, val, ileu and leu (Umbarger \& Davis, I962). Thus, one may explain in this way the necessity to add all four AAs simultaneously for optimal anti-cysteine action (Table I).

When the primary action of cysteine is overcome by leu-ileu-threo-val, growth of Escheri- 
chia coli is inhibited by the secondary effect of cysteine, which requires higher concentrations of this compound (Fig. I, curve B). Though the nature of this secondary effect is less clear than that of the primary one, we can deduce a possible mechanism from the following data: (i) the effect of cysteine was analogous to that produced by omission of glucose (Fig. 4) and by 2,4-dinitrophenol treatment (Dalgarno \& Gros, 1968). This is evidence that cysteine, as its secondary effect, causes energy depletion; (ii) at Io mM, cysteine inhibits the oxygen uptake of yeasts (Bhuvanesvaran \& Sreenivasan, 1964); (iii) cysteine inhibits the activity of cytochrome oxidase (Komlós \& Erdős, 1959); (iv) though the secondary effect of cysteine is also produced by MEA (Fig. I, 4), there is a great deal of evidence which suggest that MEA is not absorbed by the bacteria (this problem is discussed in detail by Ginsberg, 1966). Our results are also compatible with this view (Fig. 5 and Nagy et al. 1969). It is therefore reasonable to think that the sites of the secondary action of cysteine are at the cell surface. This is in good agreement with the findings cited in (iii), since cytochromes are known to be attached to the cell membrane (Reynolds, 1968).

In conclusion, we suggest that cysteine as its secondary action may inhibit the activities of membrane bound respiratory enzymes and via this action causes an energy depletion of the organisms. The inhibition of net synthesis of RNA in $\mathrm{rel}^{-}$mutants and the breakdown of 'relaxed' RNA are the consequences of this effect.

The authors thank Mrs T. Kajtor and Mrs M. Kiss for their excellent technical assistance. We also thank Drs L. Alföldi and P. Datta for their helpful discussions and for reviewing the manuscript during the formative stages, and Dr L. Alföldi for the bacterial strains he generously provided.

\section{REFERENCES}

AlföLDI, L., RASKó, I. \& KeREKES, E. (1968), L-Serine deaminase of Escherichia coli. Journal of Bacteriology 96, $1512-1518$.

Bernheim, F. (I966). Cysteamine inhibition of enzyme induction and acetate oxidation in Pseudomonas aeruginosa and its reversal by high salt concentration. Experientia 22, 80I-803.

Bhuvanesvaran, C. \& SReenivasan, A. (1964). Effect of cysteine on respiration and catalase synthesis by Saccharomyces cerevisiae. Biochemical Journal 92, 504-508.

Dalgarno, L. \& Gros, F. (1968). Completion of ribosomal particles in E. coli during inhibition of protein synthesis. Biochimica et biophysica acta $\mathbf{5 7}, 52-63$.

DATTA, P. (1967). Regulation of homoserine biosynthesis by L-cysteine, a terminal metabolite of a linked pathway. Proceedings of the National Academy of Sciences of the United States of America 58,635-64I.

DatTA, P. (1969). Regulation of branched biosynthetic pathways in bacteria. Science, New York 165, 556-562.

Ellman, G. L. (1959). Tissue sulphydryl groups. Archives of Biochemistry 82, 70-77.

GINSBERG, D. M. (1966). Effects of $\beta$-mercaptoethylamine on growth and radiation sensitivity of Escherichia coli strain TAUBAR. Radiation Research 28, 708-716.

JONES-Mortimer, M. C. (1968). Positive control of sulphate reduction in Escherichia coli. The nature of the pleiotropic cysteineless mutants of E. coli K I2. Biochemical Journal 110, 597-602.

KARI, C., NAGY, Z. \& Hernádi, F. (I97I). Effect of cysteine on inducible synthesis of $\beta$-galactosidase in Escherichia coli. Biochemical Pharmacology 20, 975-978.

KomLós, E. \& Erdős, T. (1959). Enzyme inhibitors. In Methods in Experimental Medicine (in Hungarian), vol. v, pp. 18I-227. Edited by A. Kovách. Budapest: Akadémiai Kiadó.

KoningsBerger, V. V. (I967). The regulation of inducible $\alpha$-glucosidase synthesis in yeast. In Regulation of Nucleic Acid and Protein Biosynthesis, vol. 10, pp. 310-329. Edited by V. V. Koningsberger and L. Bosch. Biochimica et Biophysica Acta Library, Amsterdam: Elsevier.

Kovács, P., Kari, C., Nagy, Zs. \& Hernádi, F. (1968). Possible explanation for the metabolic radioprotective effect of cysteine on Escherichia coli $\mathrm{B}$. Radiation Research 36, 217-224.

LEAVITT, R. I. \& UMBARGER, H. E. (I96I). Isoleucine and valine metabolism in Escherichia coli. X. The enzymatic formation of acetohydroxybutyrate. Journal of Biological Chemistry 236, 2486-249 I. 
NAGY, Z., HeRnÁdi, F., KovÁcs, P. \& VÁlYI-NAGY, T. (I968a). Correlation between the physiological state of bacteria and the radioprotective effectiveness of cysteine. Archiv für Mikrobiologie 6r, 327-334.

Nagy, Z., Hernádi, F., Kovács, P. \& VÁlyI-NAGY, T. (1968b). Radiosensitivity of Escherichia coli $15 \mathrm{~T}^{-}$ and metabolic effect of cysteine. Radiation Research 35, 652-660.

NAGY, Z., KARI, C. \& HERNÁDI, F. (I969). Growth of Escherichia coli cells in the presence of cysteine on sulphate-deficient media. Archiv für Mikrobiologie 65, 39I-400.

NAGY, Z., Kovács, P., Balázs, C. \& Hernádi, F. (1968). Preirradiation acid-soluble sulfhydryl levelchanges of the cultures of Escherichia coli ${ }_{15} \mathrm{~T}^{-}$in the presence of cysteine. Biochemical Pharmacology I7, 86r-866.

NAGY, Z., Kovács, P., Kari, C. \& HeRnÁdi, F. (I970). New data on the toxic and radioprotective effect of cysteine on Escherichia coli $\mathrm{I}_{5} \mathrm{~T}^{-}$cells. Archiv für Mikrobiologie 70, 65-7I.

NAGY, Z. \& QuinTILIANI, M. (1970). X-ray sensitivity of E. coli B cells as affected by cysteine. In Radiation Protection and Sensitization, pp. 17I-176. Edited by H. L. Moroson \& M. Quintiliani. London: Taylor \& Francis.

PASTERNAK, C. A. (1962). Sulphate activation and its control in Escherichia coli and Bacillus subtilis. Biochemical Journal 85, 44-49.

REYNOLDS, P. E. (1968). The bacterial cells: major structures. In Biochemistry of Bacterial Cell Growth, pp. 73-I 35. Edited by J. Mandelstam \& K. McQuillen. Oxford: Blackwell Scientific Publications.

Roberts, R. B., Abelson, P. H., Cowie, D. B., Bolton, E. T. \& Britten, R. J.(I957). Studies of Biosynthesis in Escherichia coli. Washington: Carnegie Institution of Washington Publications, no. 607.

Umbarger, H. E. \& Davis, B. D. (1962). Pathways of amino acid biosynthesis. In The Bacteria, vol. III, pp. I67-25I. Edited by I. C. Gunsalus \& R. Y. Stanier. New York: Academic Press.

WHELDRAKE, J. F. (1967). Intracellular concentration of cysteine in Escherichia coli and its relation to repression of the sulphate-activating enzymes. Biochemical Journal 105, 697-699. 